bp Andrzej Jeż

Diecezja Tarnowska

\title{
Homilia wygłoszona do osób konsekrowanych ${ }^{1}$
}

Pytaniem starym jak świat, które zadawali sobie wybitni wodzowie, przywódcy, opozycjoniści, męczennicy, jest kwestia: czy warto dla sprawy, w imię wyznawanych wartości, narażać własne życie? Spróbujmy jednak odwrócić to pytanie i zastanowić się: czy warto żyć jakkolwiek, podporządkować się temu, co myślą mocniejsi, bardziej wpływowi, aby tylko mieć spokój i w miarę ustabilizowaną pozycję?

Przed takim mniej więcej wyborem stanął sprawiedliwy, o którym mówi dzisiejsze pierwsze czytanie z Księgi Mądrości. Czytając tekst zauważamy, że zanim otaczający sprawiedliwego ludzie uznali, że jest niebezpieczny, próbowali go przeciągnąć na swoją stronę. I cóż się wtedy okazało? Ten człowiek nie był naiwny i nie dał się wykorzystać do ich planów. Bezbożni mówią: ,Zróbmy zasadzkę na sprawiedliwego, bo nam niewygodny" (Mdr 2, 12). Użyte w tekście oryginalnym słowo dyschrestos, które w tekście polskim zostało przetłumaczone jako ,niewygodny”, oznacza kogoś, kto nie daje się wykorzystać, dosłownie: jest „ciężki w użyciu”. I rzeczywiście ów sprawiedliwy człowiek, o którym mówi Księga Mądrości, nie dał się uczynić narzędziem w rękach bezbożnych. Jawnie sprzeciwiał się bezprawiu, wypominał błędy obyczajów - jednym słowem, był chodzącym wyrzutem sumienia.

Również z obecnej praktyki życia Kościoła wiemy, jak bardzo jego przeciwnicy chcą przeciągnąć na swoją stronę niektórych duchownych, aby użyć ich do własnych celów. Potem, gdy się to stanie, czynią ich 
w debacie o życiu i problemach Kościoła autorytetami, chociaż zdradzili swoje powołanie, nie poradzili sobie z wiernością, z wymaganiami i odeszli od Kościoła. Współcześni „,bezbożni” tak samo jak niegdyś bardzo chętnie zasilają swoje szeregi ludźmi, których udaje się im przeciągnąć na swoją stronę, a potem wykorzystać do swoich celów.

Po przeciwnej stronie stoją ludzie wierni, nieugięci, ludzie o sprawiedliwych sercach, wiarygodni świadkowie obranej drogi życia. Potrzeba odwagi, ażeby otwarcie manifestować swoje poglądy. Trzeba się też liczyć z tym, że ktoś będzie usiłował poddać je próbie. W przypadku sprawiedliwego z Księgi Mądrości była to próba ostateczna, bowiem w majestacie prawa bezbożni postanowili skazać go na śmierć. ,Zobaczmy, czy prawdziwe są jego słowa - mówią między sobą - wybadajmy, co będzie przy jego zejściu" (Mdr 2, 17). Przecież pokładał nadzieję w swoim Bogu, powinien go więc ocalić (Mdr 2, 18.20). Strategia bezbożnych ukazuje, z kim tak naprawdę walczą. Ich przeciwnikiem jest Bóg, którego prawa kwestionują, i któremu rzucają wyzwanie, prześladując Jego sługi. Czy Bóg ujmie się za sprawiedliwym? Według filozofii bezbożnych nie. Za dużo już przeżyli na tej ziemi, za dużo uczynili zła, aby wierzyć jeszcze, że Bóg przejmuje się losem sprawiedliwych. A jednak, jak mówi dalej autor Księgi Mądrości, ,,Tak pomyśleli - i pobłądzili, bo własna złość ich zaślepiła. Nie pojęli tajemnic Bożych, nie spodziewali się nagrody za prawość i nie docenili odpłaty dusz czystych" (2, 21-22). Bóg zawsze upomina się o swoich sprawiedliwych, upomina się o swoich nonkonformistów, którzy wbrew otoczeniu nie dają się zmanipulować i są wierni Jego Prawu. Bóg ratuje ich z ręki bezbożnych, a jesli już dopuści na nich śmierć i cierpienie, to nagroda dla nich będzie niezmierzona. Odważyli się przecież Mu zaufać i stali się znakiem sprzeciwu wobec świata.

Historia sprawiedliwego z Księgi Mądrości w stu procentach realizuje się w życiu Jezusa, tak jakby natchniony autor pisał o Nim, ukazując dramat odwiecznego zmagania się dobra i zła. Znak sprzeciwu dla swoich, kłopotliwy pod każdym względem dla panującej kasty kapłanów, chełpi się, że zna Boga i nazywa się Jego Synem (Mdr 2, 13) - to dostateczne powody, aby uznać Jezusa za niewygodnego. W Jego życiu również realizuje się najdramatyczniejszy ze scenariuszy, w którym bezbożni skazują Sprawiedliwego na śmierć. Dotykają Go obelgą i katuszą, na którą On rzeczywiście odpowiada łagodnością i cierpliwością (Mdr 2, 19). Skazują Go na hańbiący krzyż i wołają: ,Jeśli jesteś Synem Bożym, zejdź z krzyża” (Mt 27, 40). I znów wystawiają na próbę samego Boga, mówiąc: ,Zaufał Bogu: niechże Go teraz wybawi, jeśli Go miłuje" (Mt 27, 43). 
Bóg z miłością patrzy, jak Jego Syn wypełnia swoją misję, oddając życie za ludzi. Zaś Jezus do końca ufa swojemu Ojcu: lepiej bowiem, by wypełniła się wola Boga niż wola zalęknionego człowieka. Jezus to najsławniejszy nonkonformista w dziejach świata. Porywa się na całe jego zło i wygrywa. Staje się też najwiarygodniejszym świadkiem Boga, który pamięta o swoich sprawiedliwych, miłuje ich i ostatecznie zwycięsko wyprowadza z każdej trudnej próby.

Drodzy Bracia i Siostry!

Patrząc na życie konsekrowane, można powiedzieć, iż jest ono swoistą formą nonkonformizmu wobec stylu życia powszechnie panującego w świecie. I taką też formą winno zawsze pozostać.

Papież Franciszek zapytany o miejsce właściwe zakonnikom i siostrom zakonnym w Kościele, odpowiedział: ,Zakonnicy są prorokami [...], którzy przepowiadają, jak królestwo Boże będzie wyglądać w swojej doskonałości”2. Zaś w Liście apostolskim na Rok Życia Konsekrowanego precyzuje owo prorockie powołanie: „Prorok otrzymuje od Boga zdolność zgłębiania historii, w której żyje i interpretowania zdarzeń. [...] Potrafi rozeznać, a także jasno wskazać zło grzechu i niesprawiedliwości, bo jest wolny, nie musi odpowiadać przed innymi panami, jak tylko przed Bogiem"3.

Proroczy wymiar mają autentycznie przeżywane sluby ubóstwa, posłuszeństwa i czystości. Osoby konsekrowane, które żyją skromnie, a dobra, jakimi dysponują, przeznaczają na utrzymanie miejsc kultu, apostolstwo i dzieła miłosierdzia, są z jednej strony znakiem sprzeciwu wobec bożków pieniądza i konsumpcjonizmu, a z drugiej świadczą o możliwości budowania społeczeństwa bardziej solidarnego, wrażliwego na potrzeby bliźnich.

Ci, którzy składają ślub posłuszeństwa i przeżywają go dojrzale, są znakiem sprzeciwu wobec żądzy władzy, ale także wobec ubóstwiania demokracji, w której większość zawsze miałaby mieć rację. Natomiast radośnie przeżywany ślub czystości jest w dzisiejszym świecie znakiem sprzeciwu wobec nachalnej erotyzacji przestrzeni publicznej,

2 A. Spadaro, Intervista a Papa Francesco, „La Civiltà Cattolica“ 164 (2013), s. 464-465 (t1. pol. za: Serce wielkie i otwarte na Boga - catość wywiadu, http://www.deon.pl/religia/serwis-papieski/wywiady-franciszek/art,1,serce-wielkie-i-otwarte-na-boga.html.

3 Papież Franciszek, List apost. do zakonnic i zakonników na rozpoczęcie Roku Życia Konsekrowanego Świadkowie radości (21.11. 2014), nr II, 2. 
a zarazem proroczym świadectwem, że „Bóg sam wystarczy”, jak mawiała św. Teresa z Avila .

Aby być wiarygodnym znakiem dla świata i przyciągającą siłą, która prowadzi do wiary w Chrystusa, winniśmy rozwijać w sobie, w naszych wspólnotach, duchowość komunii. Ta duchowość winna kształtować nasz sposób myślenia, mówienia i działania, sprawiając, że Kościół będzie mógł rozwijać się w głąb i wszerz. Życie w komunii otwiera nas na dzieło misyjne - naszym wspólnym zadaniem jest nieść Chrystusa wszystkim narodom.

Duchowość komunii zauważamy w dziejach życia konsekrowanego. U założycieli i założycielek zgromadzeń i instytutów zawsze żywy był zmysł Kościoła, którego przejawem był ich pełny udział we wszystkich wymiarach życia kościelnego. Święci założyciele i założycielki kochali Kościól. Do ich przykładów musimy się nieustannie odwoływać, aby stawić opór dążeniom odśrodkowym i rozłamowym, dzisiaj szczególnie silnym w niektórych wspólnotach życia konsekrowanego w Stanach Zjednoczonych i Europie Zachodniej.

Zachowując słuszną autonomię, swoisty styl dążenia do świętości, jesteśmy wezwani, by wspólnie, w jedności serc i umysłów, budować Kościól, uczestniczyć w jego misji, porzucając pokusę realizowania własnych planów i podążania drogami niejako obok głównego nurtu Kościoła.

To my - ludzie Jezusa Chrystusa i ludzie Kościoła - winniśmy ukazywać, że jedność jest możliwa; że możliwe jest bycie wiernym, sprawiedliwym pomimo przeciwności i braku akceptacji ze strony otoczenia. Podobnie jak ów sprawiedliwy człowiek z Księgi Mądrości, za żadną cenę nie wolno nam stać się narzędziem w rękach bezbożnych, a w efekcie narzędziem walki przeciw Bogu i Jego prawom. Będąc często nonkonformistami wobec świata, ale za to naśladowcami Jezusa Chrystusa, będziemy zarazem znakiem wiarygodności Kościoła. Taki cel stale stawiajmy sobie w naszym życiu.

Homilia wygtoszona do osób konsekrowanych, [w:] Życie konsekrowane znakiem wiarygodności Kościota, red. ks. Andrzej Dudek, ks. Robert Kantor, Kraków 2016, s. 10-13 (Lumen Gentium, 2).

DOI: http://dx.doi.org/10.15633/9788374385725.03

4 Por. List pasterski Episkopatu Polski na Dzień Życia Konsekrowanego, 2.02.2016. 